\title{
TINJAUAN HUKUM BISNIS ISLAM \\ TERHADAP PRAKTIK PROMOSI PENJUALAN \\ OBAT TRADISIONAL
}

\author{
Baiq Rani Hazira
}

\begin{abstract}
ABSTRAK
Berbisnis merupakan aktivitas yang sangat dianjurkan dalam Islam dan memandang hukum promosi adalah mubah, karena merupakan bagian dari aspek bisnis atau strategi pemasaran selama promosi tidak keluar dari koridor yang telah ditetapkan dalam prinsip-prinsip ekonomi syariah. Akan tetapi, dalam praktik promosi penjualan obat tradisional di pasar Semparu seperti yang telah dijelaskan di atas sudah tidak sesuai dengan atauran yang sudah ditetapkan oleh Islam. Sehingga praktik promosi yang dilakukan oleh penjual obat tradisional di pasas Semparu termasuk kepada perbuatan yang dilarang oleh syariat Islam atau promosi tersebut haram dilakukan
\end{abstract}

Kata Kunci: Obat Tradisional, Hukum Islam, Promosi Bisnis.

\section{A. PENDAHULUAN}

Berbisnis merupakan aktivitas yang sangat dianjurkan dalam Islam. Rasulullah saw. sendiri telah menyatakan bahwa 9 dari 10 pintu rezekiadalah melaluipintuberdagang. Artinya, melalui jalan perdagangan inilah, pintu-pintu rezeki dapat dibuka, sehingga karunia Allah swt. terpancar dari padanya.

Salah satu pusat aktivitas ekonomi dalam perdagangan adalah pasar, baik pasar tradisional maupun pasar moderen.Pasar merupakan fasilitas publik yang sangat fital bagi perekonomian suatu daerah.Selain sebagai urat nadi, pasar juga menjadi barometer bagi tingkat pertumbuhan ekonomi masyarakat.Monzer Kafh menggambarkan sebuah pasar itu terbentuk dari produsen-produsen kecil dan konsumen-konsumen kecil dalam jumlah tidak tertentu. ${ }^{1}$

Keragaman para pedagang dan berbagai faktor yang mendasari baik intern maupun ektern menjadikan perilaku dan strategi berdagang para pedagang yang berbeda-beda, mulai dari mempromosikan barang, memberikan harga diskon, ataupun menjual barang-barang dengan harga yang lebih murah dibanding dengan pedagang lainnya.Mereka saling beradu strategi untuk menarik perhatian para pembeli.

1 Monzer Kafh, Ekonomi Islam (Telaah Analitik Terhadap Fungsi Sistem ekonomi Islam), alih bahasa Macmud Husein (Yogyakarta : Pustaka Pelajar, 1995), hlm, 49. 
Salah satu strategi dalam pemasaran atau marketing adalah promosi, dimana hal itu merupakan salah satu kegiatan pokok yang perlu dilakukan oleh seseorang atau pelaku usaha baik itu penyedia barang atau jasa dalam upaya untuk mempertahankan kelangsungan hidup usahanya. Promosi merupakan salah satu strategi pemasaran yang bermaksud untuk mendekatkan barang yang hendak dijual kepada konsumen.Dengan ini, promosi berfungsi mendekatkan konsumen dengan produsen, dimana yang menjadi sasaran akhir seluruh kegiatan bisnis adalah agar barang yang telah dihasilkan bisa dijual kepada konsumen. ${ }^{2}$

Berkaitan dengan strategi tersebut, dalam pandangan Islam bisnis bukan hanya tentang mencari keuntungan, tetapi keberkahan. Berbisnis tidak diperkenankan melanggar syariat Islam.Ketentuan syariat baik dalam modal, strategi, proses, maupun praktik dan seterusnya. Islam memiliki perangkatsyari'at yaitu norma agama dalam segala aspek kehidupan termasuk dalam usaha dan bisnis.

Terkait dengan hal tersebut penelitian ini penting untuk dilakukan karena pelaku usaha penjual obat di pasar Semparu telah melakukan praktik promosi dengan

${ }^{2} J u s m a l i a n i, d k k$, Bisnis Berbasis Syariah (Jakarta: Bumi Aksara, 2008).h. 6. mengatakan bahwa obat yang dia jual bisa langsung menyembuhkan segala macam penyakit dengan hanya mengkonsumsinya sekali, maka penyakit yang diderita akan langsung menghilang. Penjual juga menjanjikan kesembuhan dalam waktu singkat jika mengkonsumsi obat tersebut.dan juga penjual mengatakan bahwa dia adalah murid dari TGH. Zainudin Abdul Majid, dimana hal tersebut sebenarnya tidak penting untuk disampaikan, sehingga membuat masyarakat percaya dan akhirnya membeli obat yang mereka tawarkan. Sedangkan pelaku usaha sendiri bukanlah seorang profesional dalam bidang tersebut (dokter/ ahli kesehatan).Dikarenakan promosi yang mereka lakukan banyak masyarakat yang tertarik dan membeli produk yang mereka tawarkan.

Inaq Nurjanah merupakan salah satu pembeli yang pernah membeli obat di pasar Semparu, ia mengatakan bahwa ia membeli salah satu obat yang ditawarkan yaitu obat rematik dan asam urat dalam bentuk minyak yang terbuat dari minyak buah pinang Papua. Setelah mendengar penjual obat mengatakan bahwa obat rematik dan asam urat yang ia jual dijamin bisa langsung menyembuhkan penyakit rematik setelah mengoleskannya dan mengetahui bahwa si penjual merupakan muriddariTGH.Zainudin Abdul Majid (Maulana Syekh), maka Inaq Nurjanah akhirnya membeli 
obat rematik dan asam urat tersebut ${ }^{3}$. Akan tetapi, setelah beberapa kali mengoleskan obat tersebut dibagian yang terasa sakit Inaq Nurjanah tidak merasakan khasiat atau perubahan dari obat tersebut terhadap penyakit rematik yang ia derita. Oleh sebab itu, Inaq Nurjanah merasa telah dirugikan oleh penjual obat di pasar Semparu tersebut.

Promosi-promosi yang dilakukan akan menimbulkan kesan yang mendalam bagi konsumen sehingga bukan tidak mungkin konsumen akan membeli atau menggunakan produk/jasa tersebut. Akantetapi, semua yang mereka katakan dan janjikan terhadap konsumen perihal tentang khasiat obat yang mereka jual tidak benarbenar terjadi setelah dikonsumsi.Hal ini menyebabkan banyak konsumen yang merasa dirugikan.

Dalam hukum bisnis Islam seorang pelaku usaha atau pembisnis baik itu mikro maupun makro tidak boleh melakukan kegiatan yang dapat merugikan orang lain dalam melakukan usahanya, harus memperhatikan kenyamanan dan keselamatan orang lain disekitarnya. Pelaku usaha harus menjunjung tinggi atau mematuhi hak dan kewajibannya dan menjauhi segala bentuk tindakan yang dapat mengakibatkan kerugian untuk orang lain, karena salah satu

${ }^{3}$ Inaq Nurjanah, Pembeli, wawancara tanggal 14 Februari 2016 dasar hukum berbisnis dalam Islam adalah taqwa, jujur, adil, dapat dipercaya dan menepati janji.

Berdasarkan latar belakang diatas, maka penulis bermaksud mengangkat permasalahan tersebut dengan focus praktik promosi penjualan obat tradisional dipasar Semparu Kecamatan Kopang dan seperti apa islam memandang praktik promosi penjualan obat tradisional tersebut.

\section{B. ANALISIS}

\section{Analisis dari Segi Objek Akad}

Analisis Dari Segi Objeknya, Islam melihat konsep jual-beli itu sebagai suatu alat atau sarana untuk menjadikan manusia itu semakin dewasa dalam berpola pikir dan bertindak (melakukan aktivitas), termasuk aktivitas ekonomi.Pasar misalnya dijadikan sebagai tempat aktivitas jual-beli harus dijadikan sebagai tempat pelatihan yang tepat bagaimana manusia sebagai khalifah dimuka bumi ini, makasebenarnya jual-beli dalam Islam merupakan wadah untuk memproduksi khalifahkhalifah yang tangguh dimuka bumi. Karenanya, agar jual beli tersebut membentuk kepribadian yang Islami maka perlu ada aturannya diantaranya adalah rukun dalam jual beli.Salah satunya adalah harus adanya objek. Dalam hal ini batasan-batasan objek tersebut yaitu perlu adanya kejelasan 
dari objek yang akan diperjualbelikan. Kejelasan tersebut paling tidak harus memenuhi beberapa hal (dalam hal ini merupakan syarat barang yang diakadkan), antara lain:

1) Menjelaskan tentang legal (barang yang dibolehkan), halal ataupun suci, artinya barang tersebut dibolehkan oleh syariat Islam. Barang tersebut harus benar-benar halal dan jauh dari unsur-unsur yang diharamkan oleh Allah. Tidak boleh menjual barang atau jasa yang haram dan merusak.

2) Dapat diserah-terimakan, tidak sah menjual barang yang tidak ada atau yang berada di luar kemampuan penjual untuk menyerahkannya seperti menjual Malaqih, Madhamin atau menjual ikan yang masih dalam air, burung yang masih terbang di udara dan sejenisnya. Malaqih adalah anakyang masih dalam tulang sulbi pejantan. Sementara madhamin adalah anak yang masih dalam tulang dada hewan betina.

3) Harga yang sesuai, yaitu kualitas dan nilai yang dijual itu harus sesuai dan melekat dengan barang yang akan diperjualbelikan. Tidak diperbolehkan menjual barang yang tidak sesuai dengan apa yang diinformasikan pada saat promosi dan iklan, sebagaimana firman Allah Swt.

Artinya :"Hai orang-orang yang beriman, janganlah kamu saling memakan harta sesamamu dengan jalan yang batil, kecuali dengan jalan perniagaan yang Berlaku dengan suka sama-suka di antara kamu".

Ibnu Taimiyah membedakan dua tipe penetapan harga: tak adil dan tak sah, serta adil dan sah. Penetapan harga yang tak adil dan tak sah, berlaku atas naiknya harga akibat kompetisi kekuatan pasar yang bebas, yang mengakibatkan terjadinya kekurangan suplai atau menaikkan permintaan. Ibnu Taimiyah sering menyebut beberapa syarat dari kompetisi yang sempurna. Misalnya, ia menyatakan, "Memaksa penduduk menjual barang-barang dagangan tanpa ada dasar kewajiban untuk menjual, merupakan tindakan yang tidak adil dan ketidakadilan itu dilarang. Ini berarti, penduduk memiliki kebebasan sepenuhnya untuk memasuki atau keluar dari pasar.Sedangkan penetapan harga yang adil dan sah sebagaimana pada penjelasan di atas yaitu penetapan harga diberlakukan apabila ada kedzaliman dalam penentuan harga atau karena ada ketimpangan harga yang kiranya diperlukan adanya tafsir. 
Dan sah jika untuk kemashlahatan bersama. ${ }^{4}$

4) Mengetahui objek yang diperjualbelikan dan juga pembayarannya, agar tidak terkena faktor "ketidaktahuan", artinya objek barang dari barang tersebut harus benar-benar nyata dan bukan tipuan. Barang tersebut memang benar-benar bermanfaat dengan wujud yang tetap. Hal ini menjadikan orang yang melakukan transaksi tersebut mendapatkan kedudukan yang tinggi di sisi Allah SWT. Sebagaimana yang disabdakan Nabi SAW :

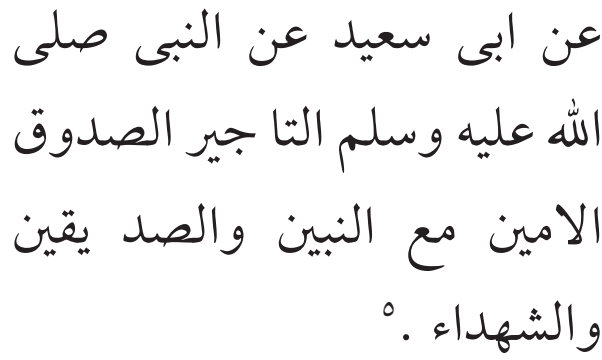

Dari keempat hal tersebut di atas, kita perlu mengetahui apakah objek jual beli obat tradisional di Desa Semparu Kecamatan Kopang tersebut sudah memenuhi beberapa kriteria di atas.Dari segi kesesuaian harga dengan kualitas terdapat manipulasi. Hal ini terlihat dari penawaran oleh

${ }^{4}$ http: / / shariaeconomy.blogspot. co.id/2008/07/penetapan-harga-dalam-islamperpektif .htmldi akses 01 Desember 2016.

${ }^{5}$ Muhammad bin isa bin abu isa AlTirmidzi, Jami Assahih Sunan Al-Tirmidzi (Bairut:darul ihya turas al araby, 1999) Juz III, h. 5 . penjual yang selalu memaparkan kelebihan yang ada pada produknya dan menafikan kekurangannya. Dengan kelebihan yang menurutnya ada pada obat tersebut, kemudian mereka memeatok harga yang tidak sesuai dengan hasilnya. Dalam hal ini ada unsur ketidak pengetahuan pembeliakankualitasyangsebenarnya pada obat tradisional tersebut, hanya saja kemudian tertarik karena bahasa menarik yang digunakan penjual.

\section{Tinjauan Hukum Bisnis Islam Terhadap Praktik Promosi Penjualan Obat Tradisional}

Islam adalah ajaran yang bertujuanmembahagiakanmanusiadi duniadanakhiratsecarabersama-sama dan saling berkaitan.Kebahagiaan hidup di dunia harus menjadi sarana untuk mencapai kebahagiaan hidup di akhirat, dan harapan kebahagiaan di akhirat menjadi ladasan motivasi dalam melakukan kegiatan di dunia yang didasarkan pada petunjuk Allah swt.dan Rasulnya. Terpisahnya kedua macam tujuan hidup ini akan melahirkan kehidupan yang timpang atau beratsebelah, sehingga tidak mencapai kebahagiaan hidup yang seutuhnya. ${ }^{6}$

Allahmenciptakanmanusialengkap beserta tugas kekhalifahannya yang berkewajiban untuk menciptakan tatanan masyarakat yang baik

${ }^{6} \mathrm{H} . \quad$ Abuddin Nata, Studi Islam Komprehensif (Jakarta: Kencana, 2011), hal. 411. 
hubungannya dengan Allah dan kemasyarakatan yang harmonis. Untuk mencapai tujuan mulia tersebut, Allah menurunkan AlQur'an sebagai hidayah yang meliputi berbagai persoalan aqidah, syariah dan akhlak. ${ }^{7}$

Alqur'an dengan tegas telah memberikan batasan-batasan bagi setiap pelaku dalam ekonomi untuk selalu bertindak dengan penuh pertanggungjawaban, baik pertanggungjawaban kepada sesama manusia lebih-lebih kepada Allah swt. berfirman dalam surat An-nisa ayat 29

Artinya :Hai orang-orang yang beriman, janganlah kamu saling memakan harta sesamamu dengan jalan yang batil, kecuali dengan jalan perniagaan yang Berlaku dengan suka sama-suka di antara kamu. Dan janganlah kamu membunuhdirimu, Sesungguhnya Allah adalah Maha Penyayang kepadamu. ${ }^{8}$

\section{Tinjauan Terhadap Praktik Promosi Penjualan Obat Tradisional}

Salah satu asas dalam hukum ekonomi Islam menurut Djamil sebagaimana yang dikemukakan oleh

${ }^{7}$ Adiwarman Azwar Karim, Sejarah pemikiran ekonomi islam (Jakarta: PT Raja Grafindo Persada, 2006), hal. 4.

${ }^{8}$ Departemen Agama RI, Al-Qur'an danTerjemahannya, hal. 122
Ismail Nawawi adalah asas kejujuran dan kebenaran (Ash-Shidiq).Jujur atau kejujuran mengacu pada aspek karakter, moral dan berkonotasi atribut positif dan berbudi luhur seperti integritas, kejujuran, dan keterus terangan, termasuk keterus terangan pada perilaku, dan beriringan dengan tidak adanya kebohongan, penipuan, dan lainnya.Selain itu, kejujuran berarti dapat dipercaya, setia, adil. ${ }^{9}$

Praktik di Pasar Semparu bahwa Para pedagang obat tradisional dalam mempromosikan produknya dengan jaminan kesehatan dalam waktu yang singkat atau berani menjamin akan khasiat yang dikandung dalam obat tersebut juga bersediadan berjanji mengembalikan uang konsumen secara penuh apabila dalam waktu yang ia sebutkan belum juga ada perubahan atas penyakit yang dideritanya.Hal ini bertentangan dengan dengan prinsip promosi dalam islam bahwa seorang pedagang harus berlaku jujur atau harus mempunyai sifat jujur dalam mempromosikan produknya, sebagaimana hadis Rasulullah Saw:

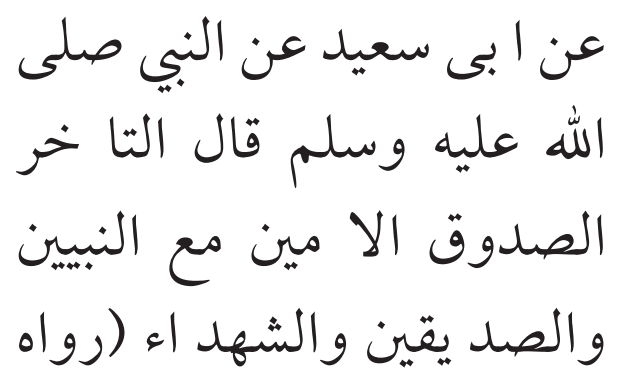

${ }^{9}$ https://id.wikipedia.org/wiki/Jujur 


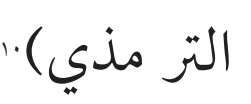

Dari Abu Sa'id ra dari Nabi Muhammadsawbersabda, "seorang pembisnis yang jujur lagi amanah maka ia akan bersama para nabi shiddiqin dan syuhada kelak di hari kiamat". (HR. Turmudzi).

Dengan prinsip kejujuran ini maka prinsip bisnis Islam sangat menjaga dan berlaku preventif terhadap kemungkinan adanya kerugian salah satu pihak yang melakukan transaksi, kerjasama atau perjanjian dalam bisnis. Karena jika salah satu pihak menyembunyikan apa yang harus diungkapkan maka kerugian rentan membenturnya.

Asas ini merupakan pokok yang esensi dan fundamental yang harus dilakukan pelaku usaha dalam setiap kegiatan usahanya. Kejujuran yang selalu berdiri tegak diatas prinsip kebenaran akan mendatangkan keberkahan. Misalnya jujur dalam menjelaskan berbagai hal terkait produk yang dipasarkan entah itu kualitas, manfaat, efek samping, sumber produksi, bahan komposisi dan yang juga harga yang layak.

Pengusaha yang jujur akan selalu bertambah partner atau konsumennya karena menaruh kepercayaan kepadanya, sebaliknya

${ }^{10} \mathrm{Al}$-Abi Isa Muhammad Bin Isa Saurah, Sunan At-Tirmidzi (Libanon: Darul Al-Qotob Al-Imiyah,1212), Jilid 2, h. 515. kecurangan dan keculasan meskipun kadang-kadang juga mendatangkan keuntungan yang besar, namun tidak akan mendatangkan berkah sehingga lambat laut konsumen akan merasa tertipu dan terkhianati karena tidak mendapatkan produk tersebut tidak sesuai dengan promosi. ${ }^{11} \mathrm{Al}-\mathrm{Qur}$ 'an menegaskan.

Artinya :Hai orang-orang yang beriman, bertakwalah kamu kepada Allah dan Katakanlah Perkataan yang benar. (Al-Ahzab : 70).

Seorang pedagang wajib berlaku jujur dalam melakukan usahanya, jujur dalam arti luas dimaknai dengan tidak berbohong, tidak menipu, tidak mengada-ada, mengungkapkan berdasarkan fakta serta tidak pernah ingkar janji dan sebagainya. Tidak jujur selain sebagai tindakan yang jelas-jelasdosa,jugaakanberpengaruh negative kepada kehidupan pribadi dan keluarga. ${ }^{12}$ Allah menegaskan dalam Al-qur'an

Artinya :Sempurnakanlah takaran dan janganlah kamu Termasuk orang-orang yang merugikan. Dan timbanglah dengan timbangan yang lurus.Dan janganlah kamu

${ }^{11}$ Sohari Sohrani, Ru'fah Abdullah, Fiqih Muamalah (Bogor: PT Ghalia Indonesia, 2011), hal. 106-107.

${ }^{12}$ Departemen Pengembangan Bisnis, Perdagangan, dan Kewirausahaan Syariah, Etika Bisnis Islam, (Jakarta: Gramata Publishing, 2011), hal. 92. 
merugikan manusia padahakhaknya dan janganlah kamu merajalela di muka bumi dengan membuat kerusakan (QS. AsSyuara' : 181-183).

Ayat tersebut menganjurkan kepada seluruh umat manusia pada umumnya, kepada para pedagang khususnya untuk berlaku jujur. Adanya penyimpangan dalam mempromosikan barang merupakan wujud penipuan yang dapat merugikan orang lain dan juga diri sendiri. Kelakuan yang menyimpang dari koridor kebenaran meskipun kecil bisa menjadi pemicu untuk melakukan tindakan penyimpangan yang lebih besar, itulah mengapa islam mengambil sikap dan tindakan sejak dini dari setiap bentuk kejahatan manusia yang akan merugikan manusia itu sendiri. ${ }^{13}$

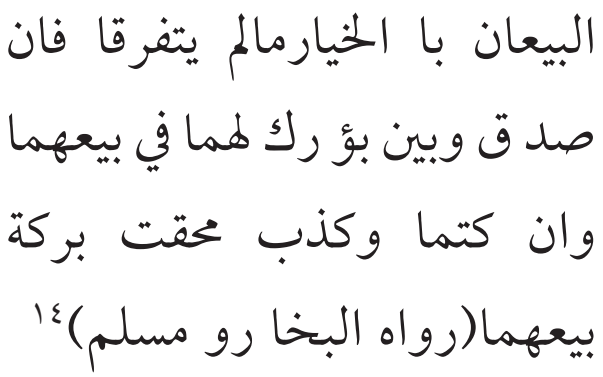

"pedagang dan pembeli keduanya boleh memilih selagi belum berpisah, apabila keduanya jujur

${ }^{13}$ Departemen Pengembangan Bisnis, Perdagangan, dan kewirausaahn syariah, Etika Bisnis Islam (Jakarta: Gramata Publishing, 2011) hal. 93

${ }^{14}$ Imam Bukhori, Shahih Bukhori, (Saudi Arabia: Baitul Afkar Ad-Dauliyah), h. 398. dan terang-terangan, maka jualbelinya akan diberkahi, namun apa bila keduanya tidak mau berterus terang serta berbohong, maka jual belinya tidak diberkahi."

\section{Tinjauan terhadap Sumpah Palsu dalam Promosi}

Sumpah berarti pernyataan yang diucapkan seseorang secara resmi dengan bersaksi kepada Tuhan atau kepada sesuatu yang dianggap suci bahwa apa yang dikatakannya itu benar. ${ }^{15}$ Kata palsu bermakna tidak tulen, asli dan tidak jujur.Sumpah palsu berarti pernyataan yang diucapkan seseorang yang tidak jujur untuk menguatkan pernyataannya. Menyinggung tentang sumpah, Allah menjelaskan dalam Al-Qur'an.

Artinya : Jangahlah kamu jadikan (nama) Allah dalam sumpahmu sebagai penghalang untuk berbuat kebajikan, bertakwa dan Mengadakan ishlah di antara manusia. dan Allah Maha mendengar lagi Maha mengetahui. (QS. Al-Baqarah : 224).

Mengomentari ayat tersebut, M. Quraish Shihab menjelaskan bahwa ayat ini sebagai larangan banyak bersumpah.Hal ini karena penyebutan nama Allah bukan pada tempatnya dapat mengantar sesorang terbiasa dengannya, sehingga dengan

${ }^{15}$ W.J.S Poerwadarminta, Kamus Umum Bahasa Indonesia, (Jakarta: Balai Pustaka, 2007), Hlm. 1158 
demikian mengantar dia berbuat dosa, bahkan menjadikan orang tidak percaya kepadanya, sehingga langkahlangkahnya untuk ishlah akan gagal. ${ }^{16}$

Dalam mempromosikan produk, setiap kegiatannya harus memperhatikan nilai-niali dari Al-Qur'an dan Al-Hadits, oleh karena itu pelaku bisnis harus memenuhi persyaratan kemanusiaan (horizontal) dan spiritual (vertikal). Untuk menghindari tindakan penjual mengelabui pembeli dengan sumpah palsu, Islam mempersyaratkan dalam promosibeberapa hal :

a. Kualitas aspek material barang, mencakup mutu bahan.

b. Aspek non material mencakup aspek halal-haramnya, baikburuknya sebuah produk. ${ }^{17}$

Nilai inti dari pemasaran syariah adalah integritas dan transparansi sehingga penjual tidak boleh bohong. Prinsip esensi yang menjadi ruh promosi adalah nilai ketuhanan (Rabbaniyah), prinsip ini harus tertanam dalam jiwa penjual sehingga ia bisa meyakini hukum syariat merupakan hukum yang paling adil, sehingga dapat mematuhinya dalam setiap promosi. Dalam setiap langkah, aktivitas kegiatan yang dilakukan harus selalu berpijak pada syariat islam. Promosi Islam meyakini

${ }^{16}$ M. Quraish Shihab, Tafsir Al-Misbah, (Ciputat: Lentera Hati, 2012), hlm. 587.

${ }^{17}$ Ali Hasan, marketing bank syariah, (Bogor: Ghalia Indonesia, 2010), hlm. 20. bahwa hukum syariat adalah hukum yang paling ideal, sempurna dan tepat untuk segala bentuk kebaikan dan mencegah segala bentuk kerusakan.

Prinsip ini mendidik seorang penjual akan merasa selalu diawasi Allah swt. Sehingga ia akan mampu untuk menghindari segala macam perbuatan yang menyebabkan orang lain tertipu atas produk-produk yang dijualnya. Dengan prinsip ini pula seorang penjual akan lebih berhatihati dalam prilaku promosinya dan berusaha untuk tidak merugikan orang lain. Namun jika penjual hanya berorientasi pada keuntungan maka ia cenderung merugikan orang lain dengan memberikan janji palsu. ${ }^{18}$

Oleh sebab itulah Rasulullah memberikan contoh dan selalu mengingatkan kepada para pedagang untuk tidak mengobral janji atau berpromosi secara berlebihan yang cenderung mengada-ada, tujuannya semata-mataagarbarangdagangannya laris terjual, yang bahkan mereka sampai berani bersumpah palsu atas nama Allah untuk menguatkan katakatanya, dan untuk menarik hati konsumen.

Adanya informasi yang berlebihan dan justru tidak benar sangat dibenci oleh Rasulullah. Terjualnya seluruh barang dagangan

${ }^{18}$ Nur Arianto Arif, Dasar-dasarpemasaran bank syariah, (Bandung: Alfabeta Bandung, 2012), hlm. 22. 
adalah dambaan setiap pedagang, tapi bukan berarti menghalalkan segala cara untuk mencapainya. Bahkan berbagai prinsip yang menjadi landasan intraksi muamalah seperti asas ilahiyah, dan insaniyah tidak diperdulikan sehingga sikap saling percayadalam kehidupan sosial akan mungkin terwujud apabila menanamkan kejujuran diantara mereka, kalau kejujuran tidak ada maka kebersamaan akan runtuh. ${ }^{19}$

Sumpah dalam jual beli itu secara mutlak hukumnya makruh, baik pelakunya seorang pendusta maupun orang yang jujur.Jika pelakunya seorangyang suka berdusta dalam sumpahnya, sumpahnya menjadi makruh yang mengarah kepada haram.Dosanya lebih besar dan adzabnya sangat pedih, dan itulah yang disebut dengan sumpah dusta. Sumpah itu, jika menjadi satu sarana melariskan dagangan, maka ia akan menghilangkan berkah jual beli dan juga keuntungan. Hal tersebut ditunjukkan oleh apa yang diriwayatkan oleh Abu Hurairah radhiyallohu 'anhu, ia berkata: "Aku pernah mendengar Rasulullohshalallahu 'alayhi wa sallam bersabda

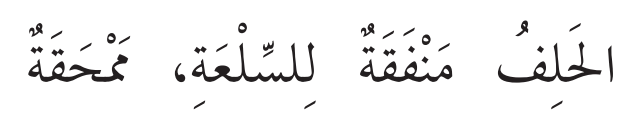

${ }^{19}$ SudirmanTebba, Membangun etos kerja perspektif tasawuf(Bandung: Pustaka Nusantara Publishing, 2003), hal. 96.

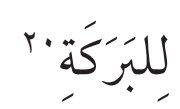

Artinya :"Sumpah itu dapat melariskan dagangan dan menghilangkan berkah." (HR. Ahmad, Al-Bukhari, Muslim dan lainnya).

Diriwayatkan oleh Al-Bukhari danMuslimdidalamkitab shahih milik keduanya.Dan lafazh di atas milik alBukhari.Silahkan lihat kitab Fat-hul Baari, jilid IV, hal. 315. Juga didasarkan pada apa yang diriwayatkan dari Abu Dzar radhiyallahu 'anhu, dari Nabi shalallahu 'alayhi wa sallam, beliau bersabda:

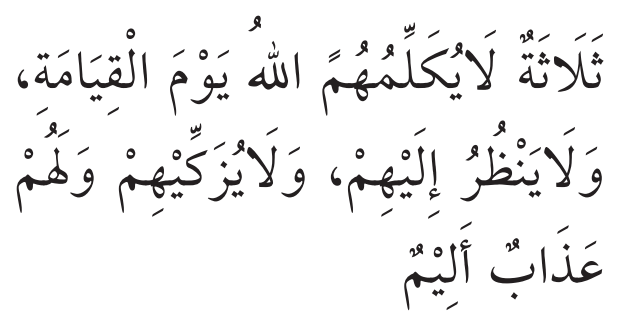

"Ada tiga golongan yang tidak akan diajak bicara oleh Allah pada hari Kiamat kelak Dia tidak melihat mereka, dan Dia juga tidak akan menyucikan mereka, serta bagi mereka adzab yang pedih."

Dia mengatakan: "Hal itu dibacakan oleh Rasulullah shalallahu 'alayhi wa sallamsebanyak tiga kali." Abu Dzarr mengatakan: "Mereka benar-benar gagal dan merugi. Siapakah orang-orang itu, wahai Rasulullah?" Beliau pun menjawab:

${ }^{20}$ Imam Muslim, Sahih Muslim, (Saudi Arabia: Baitul Afkar Ad-Dauliyah), h. 621. 


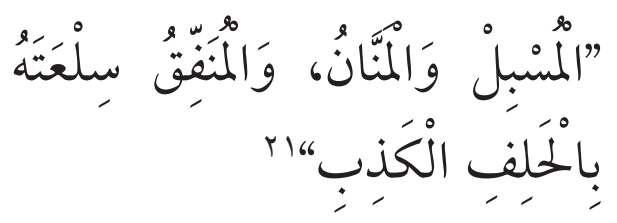

Artinya:"Priayangmemanjangkan pakaiannya di bawah mata kaki, dan orang yang menyebut-nyebut pemberiannya, serta orang yang melariskan dagangannya dengan menggunakan sumpah palsu."(HR. Muslim)

Walaupun sumpah dalam jual beli itu dilakukan dengan penuh kejujuran, maka sumpahnya tetap makruh, tetapi makruh dengan pengertian tanzih (sebaiknya dihindari) karena yang demikian itu sebagai upaya melariskan dagangan sekaligus mencari daya tarik pembeli dengan banyak mengumbar sumpah. Padahal Allah Ta'ala telah berfirman:

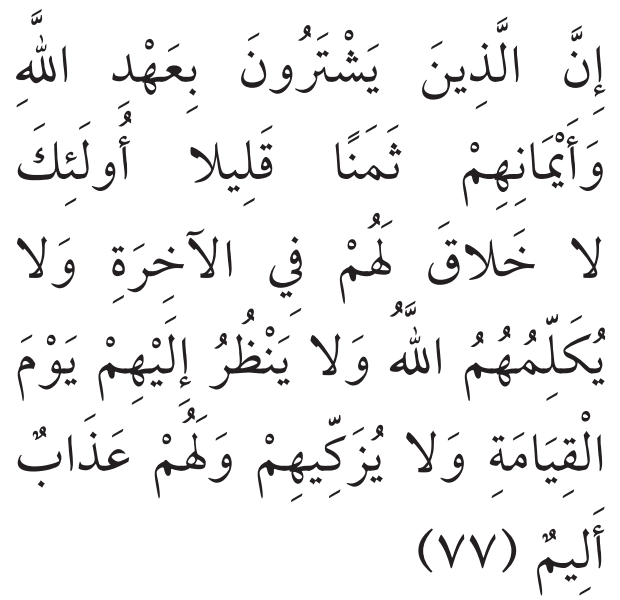

Artinya :"Sesungguhnya orangorang yang menukar janji (nya dengan) Allah dan sumpah- sumpah mereka dengan harga yang sedikit, mereka itu tidak mendapat bahagian (pahala) di akhirat, dan Allah tidak akan berkata-kata dengan mereka dan tidak akan melihat kepada mereka pada hari kiamat dan tidak (pula) akan mensucikan mereka. bagi mereka azab yang pedih."(QS. Ali Imaran: 77)

Juga didasarkan padakeumuman firman Allah Ta’ala:

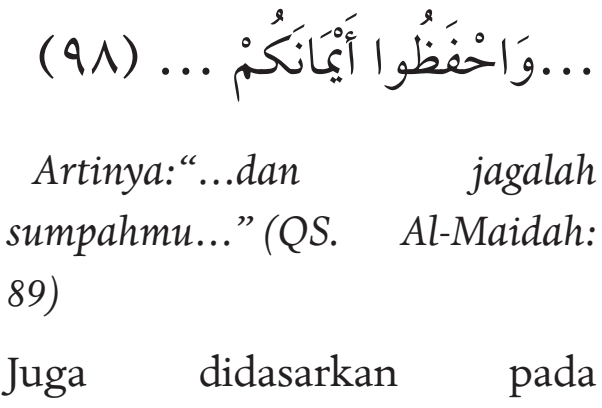
keumuman hadits yang diriwayatkan dari Abu Qatadah al-Anshari asSulami, dia pernah mendengar Rasulullah shalallahu 'alayhi wa sallambersabda:

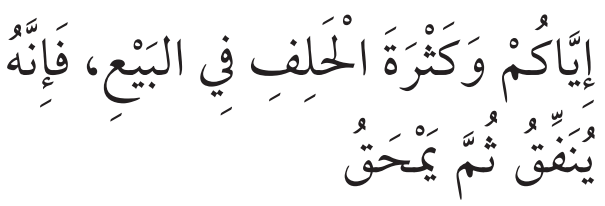

Artinya :"Hindarilah banyak bersumpah dalam jual beli, karena sesungguhnya sumpah itu memang bisamembuatlaris, tetapikemudian melenyapkan (harta). ${ }^{22}$
${ }^{21}$ Imam Muslim, Sahih Muslim(BeirutLebanon:Dar Al-Kotob Al-Ilmiyah, juz I, h. 102.
${ }^{22}$ Imam Muslim, Sahih Muslim, (Saudi Arabia: Baitul Afkar Ad-Dauliyah), h. 629. 


\section{KESIMPULAN}

Hukum Islam memandang hukum promosi adalah mubah, karena merupakan bagian dari aspek bisnis atau strategi pemasaran selama promosi tidak keluar dari koridor yang telah ditetapkan dalam prinsipprinsip ekonomi syariah. Akan tetapi, dalam praktik promosi penjualan obat tradisional di pasar Semparu seperti yang telah dijelaskan di atas sudah tidak sesuai dengan atauran yang sudah ditetapkan oleh Islam. Sehingga praktik promosi yang dilakukan oleh penjual obat tradisional di pasas Semparu termasuk kepada perbuatan yang dilarang oleh syariat Islam atau promosi tersebut haram dilakukan.

\section{DAFTAR PUSTAKA}

A. Kadir, Hukum Bisnis Syariah Dalam Al-Quran, cet. ke-2, Jakarta: Amzah, 2013.

Abdur rahmat Fatoni, Metodologi penelitian dan Teknik Penyusunan Skripsi, Jakarta: PT Asdi Mahasatya, 2006.

AnisMaisaroh, TinjauanHukumIslam Terhadap Pelaksanaan Strategi Marketing Pedagang Pasar Banjar Sari Ciamis Jawa Barat, Fakultas Syari'ah dan Hukum Universitas Islam Negeri Sunan Kalijaga,Yogyakarta. 2014.

Ali Hasan, Marketing bank syariah, Bogor: Ghalia Indonesia, 2010.
Buchari Alma, Ajaran islam dalam Bisnis,Bandung: Al-Fabeta, 1994.

BurhanBungin,MetodologiPenelitian Social : Format Kuantitatif dan Kualitatif, Surabaya: Airlangga University Press, 2001.

Burhan Ashshofa, Metodelogi Penelitian Hukum, Jakarta: PT Rineka Cipta, 2007.

Depertemen Pendidikan dan Kebudayaan, Kamus Besar Bahasa Indonesia ,Jakarta: Balai Pustaka 2011.

Departemen agama RI, Al-Qur'an dan Terjeman, Bandung: Hilal, 2005.

Departemen Pengembangan Bisnis, Perdagangan, dan kewirausaahn syariah, EtikaBisnis Islam, Jakarta: Gramata Publishing, 2011.

Hendri Suhendi, Fiqh Muamalah,Jakarta: Rajawali Pers, 2010.

Husaini Usman dan Purnomo Setiady Akbar, Metodelogi Penelitian Sosial, Jakarta: PT. Bumi Aksara, 2009.

Imam Tirmidzi, Sunan Tirmidzi,Kairo:DarulHadits,Juz III, 2010.

Imam Ibn Majah, Sunan Ibn Majah, Dar Al-kotob Al-Ilmiyah: Beyrouth-Libanon, Juz III, 2009, 
Jusmaliani., dkk, Bisnis Berbasis Syariah, cet. ke-1, Jakarta: Bumi Aksara, 2008.

Lexy J. Meleong, Metodologi Penelitian Kualitatif, Bandung: PT Remaja Radakarya, 2011.

Moh. Anief, Prinsip Umum dan Dasar Farmakologi, Yogyakarta: Gajah Mada University Press, 2004.

Monzer Kafh, Ekonomi Islam, Telaah Analitik Terhadap Fungsi Sistem ekonomi Islam, alih bahasa Macmud Husein, Yogyakarta : Pustaka Pelajar, 1995.

Mukaromah, "Hadiah Sebagai Promosi Untuk Menarik Konsumen Dalam Perspektif Hukum Islam (Studi terhadap pasal 13 dan 14 Undang-undang No. 18 tahun 1999 tentang perlindungan konsumen), Fakultas Syariah Universitas Islam Negri Kalijaga, Yogyakarta,2006.

Muhammad Arif, Etika Periklanan dalam Hukum Islam, Fakultas Syariah Universitas Islam Negri Kalijaga, Yogyakarta, 2009.
Rachman Syafe'i, Fiqh Muamalah, Bandung: Pustaka Setia, 2001.

Ruf'ah Abdulah, fikih Muamalah, Bogor: Ghalia Indonesia, 2011.

Suharsimi Arikunto, Prosedur Penelitian Suatu Pendekatan Praktik, Jakarta: Rineka Cipta, 2006.

Sugiyono, Metode Penelitian Kuantitaif dan Kualitatif $\mathrm{R}$ dan D, Bandung: CV. Alfabeta, 2007.

SudirmanTebba, Membangun etos kerja perspektif tasawuf, Bandung: Pustaka Nusantara Publishing, 2003.

Yusuf Qardhawi, Norma dan Etika Ekonomi Islam, cet. ke-1, Jakarta: Gema Insani, 1997.

Zulkifli, Obat itu Racun, Panduan Penting Memilih dan Waspada Obat,Yogyakarta: Grha Pustaka, 2009

http:/ / kbbi.web.id/

https://id.wikipedia.org/wiki/Jujur 